\title{
The Soviet Union and the Gutting of the UN Genocide Convention
}

\author{
Anton Weiss-Wendt \\ Wisconsin: The University of Wisconsin Press 2017 \\ 385 sider. ISBN 9780299312909
}

Omtalt av: Erik Kulavig [lic.phil., lektor, Syddansk Universitet, kulavig@sdu.dk]

Bogens påstand er, at hverken Sovjetunionen eller USA var særligt interesseret i bestræbelserne på at få defineret begrebet folkemord og gjort det til en international forbrydelse. Processen startede umiddelbart efter Anden Verdenskrig og kom til at foregå inden for rammerne af FN. I stedet for at blive et effektivt instrument i international politik blev det imidlertid først og fremmest til endnu en kampplads for Den Kolde Krig, hvor de to hovedkombattanter forsøgte at udnytte begrebet og konventionen til at miskreditere hinanden i verdensoffentlighedens øjne. Den sovjetiske side kæmpede med næb og kløer mod etableringen af en international domstol og ikke mindst mod, at konventionen skulle omfatte politiske grupperinger. Samtidig gjorde de alt muligt for at ramme især briterne på deres kolonipolitik og amerikanerne på apartheidspørgsmålet.

Påstanden er ikke opsigtsvækkende, og bogen rykker ikke ved den almindeligt accepterede opfattelse, men det omfattende empiriske arbejde, der ligger til grund for den, og den yderst detaljerede redegørelse for konventionens tilblivelse og den efterfølgende kamp om den bringer mere fast grund under fødderne i dette vigtige kapitel om Den Kolde Krigs historie. Selv om Sovjetunionen står tilbage som hovedskurken, lægges der ikke skjul på, at USA havde sine grunde til at modvirke konventionen. På den baggrund kan det undre, at det kun er Sovjetunionen, der optræder i bogens titel.

De første belæg for bogens påstand om den sovjetiske modstand fremlægges i de indledende tre kapitler, hvori der redegøres for forskellige aspekter af udviklingen af det, der blev kendetegnende for sovjetisk udenrigspolitik og herunder stillingtagen til internationalt samarbejde og til internationale organisationer. Grundstenen for hele denne bygning var klassekampen. Så længe der eksisterede to systemer, kapitalismen og kommunismen, var der også tale om to grundlæggende forskellige verdensopfattelser, der, når det kom til stykket, ikke kunne forenes. Den første var 
af historien dømt til død og undergang, fordi den i sin kerne var falsk, brutal og primitiv. Sovjetunionen var med socialismen på udviklingens forkant og kunne kun gå af med sejren. Efter at Vysjinskij havde overtaget ledelsen af det juridiske område i Sovjetunionen i slutningen af trediverne, udvikledes en særlig pragmatisk holdning i forhold til international lov, der betød, at den ikke længere blot skulle afvises over én kam, men udnyttes til at fremme sovjetiske interesser. Stalin betegnede det som en overgang fra dogmatisk til kreativ marxisme. Endemålet - den kommunistiske verdensorden - blev dog aldrig tabt af syne.

Det andet belæg bringes for dagen i et afsnit om den særlige sovjetiske selvretfærdighed, der kom til syne i den diplomatiske aktivitet, og som havde stærke rødder i det overordnede verdensbillede, hvor Sovjetunionen stod for det gode, herunder for fredens sag. Denne selvopfattelse afsløredes gang på gang i FN. Ikke mindst i forbindelse med brugen af vetoretten i Sikkerhedsrådet. Denne ret var Sovjetunionens betingelse for at tilslutte sig FN, og den var samtidig en garanti for, at FN ikke udviklede sig til en overnational regering, der kunne bestemme over sovjetisk politik.

Det tredje belæg gives gennem en meget detaljeret redegørelse for forskellige udkast til FN's folkemordskonvention og ikke mindst de sovjetiske overvejelser. Anton Weiss-Wendt har haft adgang til kilder, hvoraf det fremgår, at Stalin selv og udenrigsminister Molotov tog aktivt del i processen. Dokumenterne bærer håndskrevne kommentarer og understregninger foretaget af de to herrer. Af dette kan det aflæses, at det overordnede ideologiske verdensbillede i virkeligheden holdt Sovjetunionen på afstand af internationalt samarbejde. Hvad angår folkemordsspørgsmålet, så man det som et slet skjult forsøg på at underminere det sovjetiske styres legitimitet fra de imperialistiske magters side. Man opfattede det med andre ord som et forsøg på at anklage de sovjetiske ledere for socialt folkemord i forbindelse med revolutionen og borgerkrigen, herunder fratagelse af borgerrettigheder og ejendom fra det gamle borgerskab, mens man selv så det som et led i en historisk berettiget revolutionær kamp. Folkemord var i de sovjetiske ideologers øjne et fascistisk eller nazistisk fænomen af racemæssig karakter, og det ville man gerne være med til at fordømme og dømme. En amerikansk kritik af det endelige udkast til Folkemordskonventionen viser, hvor dygtige de sovjetiske forhandlere efter deres opfattelse havde været til at få deres synspunkter igennem. Med bidende ironi foreslog man således følgende titel til dokumentet: "Til forhindring af og straf for folkemordskriminalitet, som det blev praktiseret af nazisterne, men ikke som det bliver praktiseret nu i sovjetblokken" (s. 144).

Bogen bekræfter, at den polsk-jødiske jurist Raphael Lemkin (1900-1959), der i 1941 flygtede til USA, var hovedmanden i bestræbelserne på at få vedtaget konventionen. Weiss-Wendt beskriver ham både som idealist og som et instrument for de stridende parter under Den Kolde Krig. Han var nærmest besat af tanken om at sætte lighedstegn mellem nazismen og kommunismen, hvad angik folkemord, og han tøvede ikke med at bakke de emigrantkredse fra Østeuropa, der befandt sig i USA, op i deres påstand om, at Sovjetunionen begik folkemord i deres hjemlande. Forfatteren er af den opfattelse, at Lemkin havde en vigtig sag, men at hans iver for 


\section{0 | ERIK KULAVIG}

at få den ført igennem gjorde ham for radikal og for ukritisk over for sine støtter. Det kan lige som stormagternes tøven i sig selv have modvirket processen.

Bogen om folkemordets juridiske og politiske historie i Europa efter Anden Verdenskrig er ikke nogen easy-reader. Det lægger emnet heller ikke op til, men en kritisk redaktør kunne med fordel have kappet nogle af sidegrenene af det undertiden vel vildtvoksende træ af, og flere af de mange detaljer kunne have været henvist til noteapparatet eller udeladt. Som det står nu, skal man være mere end almindeligt interesseret $\mathrm{i}$ emnet for at bevare interessen og overblikket. 